\title{
Tight Money and the Sustainability of Public Debt*
}

\author{
Sergey Pekarski \\ National Research University Higher School of Economics
}

\begin{abstract}
In the celebrated paper "Some Unpleasant Monetarist Arithmetic," Sargent and Wallace (1981) show that tight monetary policy is not feasible unless it is supported by appropriate fiscal adjustment. In this paper, we explore a simple forwardlooking monetary model to show that an anticipated decrease in the growth rate of base money is not necessarily characterized by "unpleasant arithmetic." This is due to a possible transitory gain in seigniorage supported by a temporal decrease in the real interest rate, which keeps public debt on a sustainable path. An important implication is that an increase in the present value of future budget deficits does not necessarily have inflationary consequences.
\end{abstract}

JEL Codes: E41, E52, E61, E63.

\section{Introduction}

The extremely high level of public debt challenges macroeconomic policy in the United States and other developed countries in the aftermath of the 2008-09 financial crises. There are serious doubts as to whether governments are able to adjust fiscal policy to keep public debt sustainable (see, e.g., Leeper and Walker 2011). On the other hand, there are concerns about the inflationary consequences of past and projected budget deficits, and about the ability of central banks to control inflation and provide governments with positive remittances in these circumstances (see, e.g., Cochrane 2011; Greenlaw et al. 2013).

* Support from the Basic Research Program of the National Research University Higher School of Economics is gratefully acknowledged. The author is indebted to referees for valuable comments. Author contact: 101000, Myasnitskaya str. 20, Moscow, Russia. E-mail: spekarski@hse.ru. 
In the celebrated paper "Some Unpleasant Monetarist Arithmetic" (referred to as UMA in this paper), Sargent and Wallace (1981) showed that tight monetary policy is not feasible under the regime of fiscal dominance. Without fiscal adjustment, a decrease in the growth rate of base money requires higher seigniorage revenue and, thus, a higher growth rate of base money in the future to stabilize growing public debt. Moreover, if expectations are forward looking, then tighter money leads to higher inflation not only in the future, but immediately.

This paper explores the conditions under which permanently tighter monetary policy is feasible without fiscal adjustment in the sense that it does not upset the sustainability of public debt. The tight money paradox sparked an interesting discussion (see, e.g., Bhattacharya and Kudoh 2002 and Nikitin and Russell 2006 for a well-structured survey on recent contributions to UMA). Our research is close to that of Buffie (2003a), who shows the equilibrium path of real money balances and public debt "overlooked" by Sargent and Wallace (1981) and Drazen (1985) which gives "pleasant monetarist arithmetic" for tight monetary policy. This path, followed by a decrease in the growth rate of base money, is associated with the transitory gain in seigniorage revenue and thus does not require extra revenues from money creation or fiscal adjustment to stabilize public debt. However, this is only possible under certain restrictions on preferences and the parameters of the policy shift (the timing and magnitude of the change in the growth rate of base money).

The monetary growth model employed in Drazen (1985) and Buffie (2003a) is essentially a non-linear dynamic system for real money balances and real public debt, which has an unstable steady state. This setup entails several inconveniences. First, working with a linearized system does not allow for significant departures from the steady state. The case of pleasant monetarist arithmetic, explored by Buffie (2003a), however, requires a relatively long transitory path. Second, Drazen (1985) and Buffie (2003a) allow for an initial jump in real money balances due to the jump in the price level. This is natural in the study of dynamics associated with a saddle-type steady state, but hardly justified for the vector field generated by an unstable node. Third, the unstable steady state requires imposing an assumption that the government and the central bank have to stabilize the economy at the end of a temporary shift in the monetary policy by fixing the budget deficit and the growth rate of base money 
at certain levels. Finally, most of the literature on UMA assumes a constant real interest rate, which in turn follows from the assumption of additive separability in consumption and money utility.

In this paper, we use a framework of forward-looking monetary dynamics proposed by Sargent and Wallace (1973). It helps to elude the aforementioned problems. An important element of our analysis which is new to the UMA literature is that we allow for the preannouncement (or anticipation) of future monetary policy tightening. Preannouncement generates transitional dynamics in the system up to the time of the actual policy switch and, unlike in Buffie's model, unambiguously provides a transitory gain in seigniorage. The intuition is straightforward: the anticipation of a decrease in the growth rate of base money in the future leads to higher demand for real money balances, which results in higher seigniorage for the current growth rate of base money. We provide the evidence that the transitional gain in seigniorage can be significant.

Instead of the ad hoc assumption, common in the UMA literature, that public debt must be stabilized by a certain date in the future, we impose the principle of sustainable macroeconomic policy, which requires the present discounted value of future budget surpluses and seigniorage revenues to provide appropriate backing for the accumulated public debt. This helps us to revisit the crucial role of the interest rate on public debt. One would expect that by accelerating the growth of public debt, a higher interest rate should make monetarist arithmetic even more unpleasant. Quite the contrary, following a traditional framework of additively separable utility, we show that when the constant real interest rate is higher than a certain threshold value, the possibility of a transitory gain in seigniorage, followed by a gradual or anticipated decrease in the growth rate of money, implies a higher present value of future seigniorage, which keeps public debt sustainable1:2 Thus, tight monetary policy is feasible without fiscal adjustment. We also question the feasibility of anticipated monetary policy tightening in the case of non-separable

\footnotetext{
${ }^{1}$ This result is in sharp contrast with one obtained by Chadha and Nolan (2004), who show that permanent budget deficits imply an upper bound on the trajectory of the short-term real interest rate, which is assumed to be under indirect control of monetary authorities.

${ }^{2}$ In a recent contribution to UMA literature, Uribe (2016) also employs a framework of sustainable macroeconomic policy. Reis (2015) discusses the crucial role of the present value of seigniorage in the context of central bank solvency.
} 
utility. Under conventional assumption of Edgeworth complementarity between consumption and real money balances, the real interest rate undergoes a transitional decrease which supports transitional gain in seigniorage. Monetarist arithmetic can be pleasant if the steady-state real interest rate is either above an upper threshold or below a lower threshold. This is another contribution to UMA literature.

While the main focus of the paper is on the role of a possible transitory gain in seigniorage which allows for pleasant arithmetic of tight monetary policy, the framework allows for a broader discussion of the interaction between monetary and fiscal policy. In particular, we also explore the feasibility of an anticipated loosening of monetary policy under different regimes implied by the interest rate on public debt. This is also novel in the UMA literature. While the unpleasant consequences of monetary policy tightening received a great deal of attention, the possibly unpleasant consequences of anticipated monetary policy loosening for the sustainability of public debt have been overlooked. We also explore the necessary accommodation in monetary policy following an increase in budget deficits. The proposed extension to the fiscal theory of inflation adds to the discussion of the (un)avoidable inflationary consequences of public debt and to the modern discussion of the current fiscal-monetary nexus. In addition, we question the validity of our results obtained in a traditional monetary model within a framework of the modern fiscal theory of the price level proposed by Sims (1994) and Woodford (1995). We argue that while it provides an alternative view on the fiscal roots of inflation, its framework actually does not allow the replication of the mechanism of either unpleasant or pleasant monetarist arithmetic.

The rest of the paper is organized as follows. Section 2 presents an endowment-economy model to study the impact of monetary policy on the dynamics of real money balances, inflation, and real interest rate. In section 3 we explore the mechanism of how a preannounced monetary policy tightening may give rise to "pleasant monetarist arithmetic." This is done first for the simple case of separable utility that implies a constant real interest rate. Section 4 provides a generalization of the result for the case of non-separable utility and a variable real interest rate. In section 5 we question the relevance 
of UMA in the context of the fiscal theory of the price level and discuss additional issues arising from the possible endogeneity of budget deficits and some practical implications of the proposed extension of UMA. The final section concludes.

\section{The Model}

Consider a representative agent with an infinite time horizon who maximizes the lifetime utility from consumption and real money balances:

$$
\max _{c, m} \int_{0}^{\infty} U\left(c_{t}, m_{t}\right) e^{-\rho t} d t
$$

Here $c_{t}$ is consumption, $m_{t}=M_{t} / P_{t}$ is the quantity of real money balances, $\rho$ is a subjective discount rate, and $U(c, m)$ is an instantaneous utility function which is increasing and strictly concave in $c$ and $m$. The budget constraint is given by the following equation:

$$
P_{t} c_{t}+\dot{M}_{t}+\dot{B}_{t}=P_{t} y+i_{t} B_{t}-P_{t} T_{t}
$$

where $P_{t}$ is the price level; $y$ is the real income (flow endowment), which we assume for simplicity to be constant; $T_{t}$ stands for lumpsum taxes; $B_{t}$ is the nominal value of public debt; and $i_{t}$ is the nominal interest rate on public debt. The representative agent spends his total disposable nominal income on consumption and saving. The latter consists of increments in the base money and in government bonds. The budget constraint (2) can be written in terms of real variables for convenience:

$$
\dot{a}_{t}=y+r_{t} a_{t}-c_{t}-\left(r_{t}+\pi_{t}\right) m_{t}-T_{t}
$$

where $a_{t}=m_{t}+b_{t}$ stands for the real assets of the representative agent, $b_{t}=B_{t} / P_{t}$ is the real value of public debt, and $\pi_{t}$ is the rate of inflation 3 Under the perfect foresight hypothesis, $r_{t}=i_{t}-\pi_{t}$ is the real interest rate.

\footnotetext{
${ }^{3}$ We consider the real (indexed) public debt in the tradition of UMA literature. The case of the nominal public debt is discussed in the context of the modern fiscal theory of the price level in section 5.1.
} 
The operational budget deficit is defined as the government expenditure, $G$, minus net taxes, $T$, both taken for simplicity to be constant, plus debt service. The government finances the deficit by new borrowings and seigniorage, $S_{t}=\dot{M}_{t} / P_{t}=\dot{m}_{t}+m_{t} \pi_{t}$ :

$$
G-T+r_{t} b_{t}=S_{t}+\dot{b}_{t} .
$$

The budget constraint of the representative agent (3) and the budget constraint of the government (4) determine the constant level of consumption:

$$
y=c+G .
$$

The first-order conditions for the intertemporal optimization problem (1) and (3) are

$$
\begin{gathered}
U_{c}\left(c, m_{t}\right)=\lambda_{t}, \\
U_{m}\left(c, m_{t}\right)=\lambda_{t}\left(r_{t}+\pi_{t}\right), \\
\dot{\lambda}_{t}=\lambda_{t}\left(\rho-r_{t}\right), \\
\lim _{t \rightarrow \infty} \lambda_{t} q_{t} e^{-\rho t}=0, \quad q_{t}=a_{t}, m_{t}, b_{t},
\end{gathered}
$$

where $\lambda_{t}$ is the co-state variable. Equations (6) and (7) determine the demand for money, $m^{D}=m\left(i_{t}\right)$.

By combining equations (6)-(8) and the dynamics of the real money balances, $\dot{m}_{t} / m_{t}=\mu_{t}-\pi_{t}$, where $\mu_{t}=\dot{M}_{t}^{s} / M_{t}^{s}$ is the growth rate of base money, we arrive at the law of motion for the real money balances:

$$
\dot{m}_{t}=\frac{U_{c}\left(c, m_{t}\right) m_{t}}{U_{c}\left(c, m_{t}\right)+U_{c m}\left(c, m_{t}\right) m_{t}}\left(\rho+\mu_{t}-\frac{U_{m}\left(c, m_{t}\right)}{U_{c}\left(c, m_{t}\right)}\right) .
$$

In the model of an endowment economy, the dynamics of real money balances is governed by the monetary policy, which sets the path of $\mu_{t}$. In turn, the dynamics of inflation and real interest rate is driven by $\mu_{t}$ and $m_{t}$ :

$$
\begin{aligned}
\pi_{t}= & \mu+\frac{U_{c}\left(c, m_{t}\right)}{U_{c m}\left(c, m_{t}\right) m_{t}}\left(1+\frac{U_{c}\left(c, m_{t}\right)}{U_{c m}\left(c, m_{t}\right) m_{t}}\right)^{-1} \\
& \times\left(\frac{U_{m}\left(c, m_{t}\right)}{U_{c}\left(c, m_{t}\right)}-\rho-\mu_{t}\right),
\end{aligned}
$$




$$
r_{t}=\rho+\left(1+\frac{U_{c}\left(c, m_{t}\right)}{U_{c m}\left(c, m_{t}\right) m_{t}}\right)^{-1}\left(\frac{U_{m}\left(c, m_{t}\right)}{U_{c}\left(c, m_{t}\right)}-\rho-\mu_{t}\right) .
$$

The dynamic government budget constraint (4) together with the transversality condition (9) gives the present-value budget constraint:

$$
b_{t}=\int_{\tau=t}^{\infty}\left(S_{\tau}-d\right) e^{\int_{z=t}^{\tau} r_{z} d z} d \tau
$$

The principal message of UMA is that public debt sustainability implies a joint constraint on fiscal and monetary policy: at each time $t$ and for every volume of accumulated public debt $b_{t}$, future trajectories of the real primary budget deficit $d=G-T$ and seigniorage $S_{t}$ must satisfy (13) 4 Let us also assume, following Sargent and Wallace's (1981) original assumptions, that fiscal policy is dominant and the instrument of monetary policy is the growth rate of base money. That is, when monetary authorities set the trajectory of the growth rate of base money, they consider future budget deficits as given. For an exogenous dominant fiscal policy, (13) determines the constraint on the present discounted value of future seigniorage, while its transitory dynamics may in fact be arbitrary. This is the crucial point in our analysis. Thus, any change in the course of monetary policy which produces a decrease in the present discounted value of future seigniorage violates the sustainability constraint. To be precise, we consider the feasibility of changing monetary policy in the future in the following sense.

Definition. Monetary policy is feasible under a regime of fiscal dominance if it does not lead to a decrease in the expected present discounted value of future seigniorage, which violates the sustainability constraint (13).

To examine whether tighter monetary policy is feasible under a regime of fiscal dominance, we explore several "textbook" theoretical

\footnotetext{
${ }^{4}$ Sargent and Wallace (1981) and subsequent authors (Drazen 1985; Buffie 2003a) assume that monetary policy should be endogenous to the dynamics of public debt: when debt reaches some upper limit and cannot be stabilized by means of fiscal adjustment, it has to be monetized. This ad hoc assumption is in line with (13).
} 
experiments on the forward-looking dynamics for different classes of utility function.

\section{The Case of a Constant Real Interest Rate}

\subsection{Sargent-Wallace (1973) Forward-Looking Monetary Dynamics}

Consider first the case of additive separability in consumption and real money balances utility:

$$
U(c, m)=v(c)+w(m), \quad v_{c}, w_{m}>0, v_{c c}, w_{m m}<0 .
$$

In this case condition (6) determines the constant level of the costate variable and thus condition (8) determines the constant real interest rate:

$$
\begin{aligned}
& \lambda=v_{c}(y-G), \\
& r=\rho .
\end{aligned}
$$

To simplify the exposition further, consider the utility from real money balances of the form

$$
w(m)=m\left(\alpha_{1}-\alpha_{2} \ln m\right), \quad \alpha_{1}, \alpha_{2}>0 .
$$

Then, equations (7), (15), and (16) determine the Cagan money demand function:

$$
m^{D}=A e^{-\alpha \pi},
$$

where $\alpha=v_{c}(y-G) / \alpha_{2}$ is constant semi-elasticity, and scale parameter $A=\exp \left(\left(\alpha_{1}-\alpha_{2}-\rho v_{c}(y-G)\right) / \alpha_{2}\right)$ is normalized to unity 5 Equation (10) gives

$$
\dot{m}_{t}=m_{t}\left(\mu_{t}+\frac{1}{\alpha} \ln m_{t}\right) .
$$

\footnotetext{
${ }^{5}$ While $A$ depends on $\rho$, this normalization does not affect the dynamics of inflation, log of real money balances, and seigniorage. It also does not alter the proposition in section 3.3 .
} 
The corresponding dynamics of inflation is given by

$$
\dot{\pi}_{t}=-\frac{1}{\alpha}\left(\mu_{t}-\pi_{t}\right)
$$

which is the starting point in the classical forward-looking dynamic model by Sargent and Wallace (1973). Imposing the transversality condition, (9), we arrive at fundamental forward-looking solutions to $(19)$ and $(20) \cdot 6$

$$
\begin{aligned}
m_{t} & =e^{-\int_{\tau=t}^{\infty} \mu_{\tau} e^{-\frac{1}{\alpha}(\tau-t)} d \tau}, \\
\pi_{t} & =\frac{1}{\alpha} \int_{\tau=t}^{\infty} \mu_{\tau} e^{-\frac{1}{\alpha}(\tau-t)} d \tau .
\end{aligned}
$$

Seigniorage, $S_{t}=\mu_{t} m_{t}$, is thus determined by the current and future monetary policy:

$$
S_{t}=\mu_{t} e^{-\int_{\tau=t}^{\infty} \mu_{\tau} e^{-\frac{1}{\alpha}(\tau-t)} d \tau}
$$

In what follows, we assume that the economy operates on the increasing part of the inflation-tax Laffer curve, where money demand is inelastic. In this case a permanent unanticipated decrease in the growth rate of base money from $\mu=\mu_{0}$ to $\mu_{1}<\mu_{0}$ reduces seigniorage from $S_{0}=\mu_{0} e^{-\alpha \mu_{0}}$ to $S_{1}=\mu_{1} e^{-\alpha \mu_{1}}<S_{0}$. Its present discounted value also decreases, which leads to a violation of (13). Thus, such monetary policy tightening is not feasible under fiscal dominance. This resembles the essence of UMA.

\subsection{A Permanent Anticipated Decrease in the Growth Rate of Base Money}

Now let us show that monetary policy tightening may be feasible if it is preannounced. When a permanent decrease in $\mu$ is anticipated, seigniorage is unambiguously higher than its initial steadystate level and rises during the transition dynamics. Consider the following theoretical experiment. Initially, the growth rate of base

\footnotetext{
${ }^{6}$ Sargent and Wallace (1973) solve equation (20) by imposing terminal condition $\lim _{t \rightarrow \infty} \pi(t) \exp \left(-\alpha^{-1} t\right)=0$.
} 
money is $\mu_{t}=\mu_{0}$. At time $t_{A}$ the central bank announces that in the future, starting from $t_{S}>t_{A}$, the growth rate of base money will be decreased to $\mu_{t}=\mu_{1}>\mu_{0}$. The dynamics of real money balances, inflation, and seigniorage are as follows: 7

$$
\begin{aligned}
& m_{t}=\left\{\begin{array}{l}
e^{-\alpha \mu_{0}}, \quad t<t_{A}, \\
e^{-\alpha \mu_{0}+\alpha\left(\mu_{0}-\mu_{1}\right) e^{-\frac{1}{\alpha}\left(t_{S}-t\right)}}, \quad t_{A} \leq t<t_{S}, \\
e^{-\alpha \mu_{1}}, \quad t \geq t_{S} .
\end{array}\right. \\
& \pi_{t}=\left\{\begin{array}{l}
\mu_{0}, \quad t<t_{A}, \\
\mu_{0}-\left(\mu_{0}-\mu_{1}\right) e^{-\frac{1}{\alpha}\left(t_{S}-t\right)}, \quad t_{A} \leq t<t_{S}, \\
\mu_{1}, \quad t \geq t_{S} .
\end{array}\right. \\
& S_{t}=\left\{\begin{array}{l}
\mu_{0} e^{-\alpha \mu_{0}}, \quad t<t_{A}, \\
\mu_{0} e^{-\alpha \mu_{0}+\alpha\left(\mu_{0}-\mu_{1}\right) e^{-\frac{1}{\alpha}\left(t_{S}-t\right)}}, \quad t_{A} \leq t<t_{S}, \\
\mu_{1} e^{-\alpha \mu_{1}}, \quad t \geq t_{S} .
\end{array}\right.
\end{aligned}
$$

Initially, the money market is in a steady state. The announcement at time $t_{A}$ leads to discrete jumps in real money balances, $\Delta \ln m_{t_{A}}=-\alpha\left(\mu_{1}-\mu_{0}\right) e^{-(1 / \alpha)\left(t_{S}-t_{A}\right)}>0$, in inflation, $\Delta \pi_{t_{A}}=\left(\mu_{1}-\mu_{0}\right) e^{-(1 / \alpha)\left(t_{S}-t_{A}\right)}<0$, and in seigniorage, $\Delta S_{t_{A}}=$ $-\mu_{0} e^{-\alpha \mu_{0}}\left(1-e^{-\alpha\left(\mu_{1}-\mu_{0}\right) e^{-(1 / \alpha)\left(t_{S}-t_{A}\right)}}\right)>0$. Figure 1 shows the time paths of the variables 8

Up to time $t_{S}$, when monetary policy shifts, the inflation rate gradually decreases, while the real money balances gradually increase to the new steady level. Seigniorage gradually increases on the interval $t_{A}<t<t_{S}$ and undergoes another discrete jump at time $t_{S}, \Delta S_{t_{S}}=\left(\mu_{1}-\mu_{0}\right) e^{-\alpha \mu_{1}}<09$ The new steady-state value of seigniorage is lower than it was initially. However, this does not unambiguously lead to a decrease in its present discounted value at time $t_{A}$. If the constant real interest rate is relatively high, then the

${ }^{7}$ The derivation of equations $(24)-(25)$ is rather straightforward. It requires the detachment of appropriate time sub-intervals (see, e.g., Turnovsky 2000).

${ }^{8}$ For the sake of space, figure 1 presents only the dynamics of $\mu, m$, and $S$. The time path of $\pi$ is simply a regular reflection of the time path of $m$.

${ }^{9}$ Formally, we cannot interpret transitory dynamics as a movement along the inflation-tax Laffer curve, as it shows only steady states. Supplementary calculations show that the transitional growth in seigniorage is driven by an increasing pure seigniorage, $\dot{m}_{t}$, while the inflation tax, $\pi_{t} m_{t}$, actually decreases along the transitional path. 
Figure 1. Permanent Anticipated Decrease in the Growth Rate of Base Money under a Constant Real Interest Rate
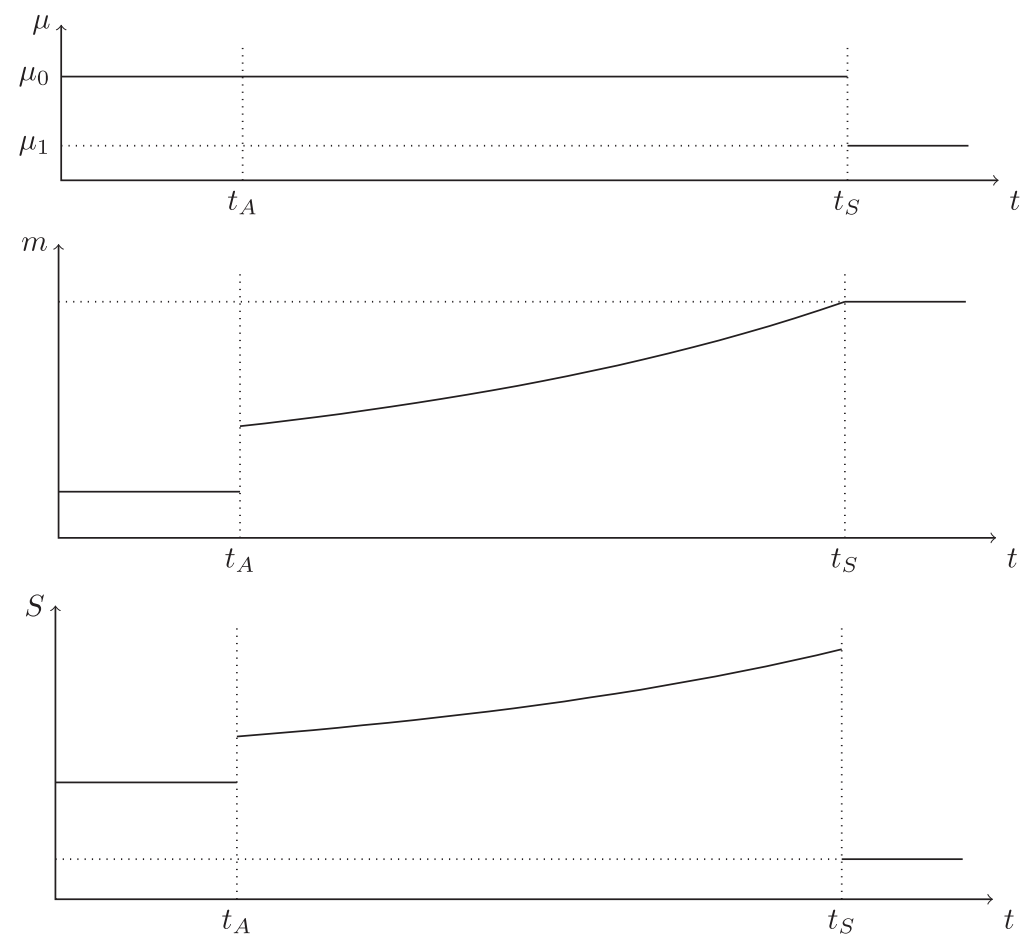

present value of future seigniorage revenues may increase, because the seigniorage was temporally higher than its initial value. Thus, unlike the case of unexpected policy change, anticipated tight monetary policy may be feasible. Section 3.3 provides a formal analysis of this issue. Moreover, we can easily generalize the analysis by considering either tighter or looser monetary policy. This is important, as an anticipated policy loosening may in fact destroy the sustainability of public debt.

\subsection{Different Policy Regimes Implied by the Interest Rate on Public Debt}

Consider the behavior of the sustainable level of public debt in the case of a permanent anticipated change (either an increase or a 
decrease) in the growth rate of base money. Substituting (26) into (13) yields

$$
b_{t}=\left\{\begin{array}{c}
\frac{\mu_{0} e^{-\alpha \mu_{0}}-d}{r}, \quad t<t_{A} \\
\int_{\tau=t}^{t_{S}} \mu_{0} e^{-\alpha \mu_{0}+\alpha\left(\mu_{0}-\mu_{1}\right) e^{-\frac{1}{\alpha}\left(t_{S}-\tau\right)}-r(\tau-t)} d \tau \\
\quad+\frac{\mu_{1} e^{-\alpha \mu_{1}-r\left(t_{s}-t\right)}}{r}-\frac{d}{r}, \quad t_{A} \leq t<t_{S}, \\
\frac{\mu_{1} e^{-\alpha \mu_{1}}-d}{r}, \quad t \geq t_{S} .
\end{array}\right.
$$

At time $t_{A}$ sustainable level of public debt undergoes a discrete change of size:

$$
\begin{aligned}
\Delta b_{t_{A}}= & \int_{\tau=t_{A}}^{t_{S}} \mu_{0} e^{-\alpha \mu_{0}+\alpha\left(\mu_{0}-\mu_{1}\right) e^{-\frac{1}{\alpha}\left(t_{S}-\tau\right)}-r\left(\tau-t_{A}\right)} d \tau \\
& +\frac{1}{r}\left(\mu_{1} e^{-\alpha \mu_{1}-r\left(t_{s}-t_{A}\right)}-\mu_{0} e^{-\alpha \mu_{0}}\right) .
\end{aligned}
$$

This change reflects the adjustment in the expected present discounted value of future seigniorage revenues following the announcement of a future monetary policy shift. This could be perceived as feasible if $\Delta b_{t_{A}} \geq 0$. The complexity of (28) makes it difficult to derive closed-form conditions for the positive value of $\Delta b_{t_{A}}$. However, it is possible to characterize it as a function of $\mu_{1}$ and $r$. The first term on the right side of (28) is always positive and decreasing in both $\mu_{1}$ and $r$. The second term is positive if $\mu_{1}$ is sufficiently higher than $\mu_{0}$, but not falling onto the wrong side of the inflationtax Laffer curve, and $r$ is relatively small. If $\mu_{1}<\mu_{0}$, then the second term is negative. Its derivative with respect to $r$ is positive if $\left(1+r\left(t_{s}-t_{A}\right)\right) e^{-r\left(t_{s}-t_{A}\right)}<\mu_{0} e^{-\alpha \mu_{0}} / \mu_{1} e^{-\alpha \mu_{1}}$, which holds for relatively high values of $r$ (or, equivalently, if the time interval between the announcement and implication of the policy is relatively long), and negative otherwise. In what follows we show that the feasibility of tighter or looser monetary policy in the future depends crucially on the interest rate on public debt.

Proposition. There is a unique value of $\bar{r}$ for which any anticipated shift in monetary policy is not feasible. For any $r>\bar{r}$, anticipated tighter monetary policy is feasible, while anticipated looser monetary policy is not feasible. If $r<\bar{r}$, then anticipated looser monetary policy is feasible, while anticipated tighter monetary policy is not feasible. 
Proof. When $\mu_{1}=\mu_{0}$, that is, when policy does not change, the gain $\Delta b_{t_{A}}$ is zero. At the same time, the marginal gain $d\left(\Delta b_{t_{A}}\right) / d r$ evaluated at $\mu_{1}=\mu_{0}$ is also zero for any $r$. To determine the level of $r$ that delimits the regimes of low and high interest rates for the monetary policy, one needs to find condition for the zero marginal gain $d\left(\Delta b_{t_{A}}\right) / d \mu_{1}$ also at $\mu_{1}=\mu_{0}$. This is given by the equation

$$
\frac{1-\alpha \mu_{0}}{\alpha^{2} \mu_{0} r}+\frac{1}{\alpha \mu_{0}}=e^{\left(r-\frac{1}{\alpha}\right)\left(t_{S}-t_{A}\right)} .
$$

Under the assumption that the economy operates on the increasing part of the inflation-tax Laffer curve, that is, $\mu_{0}<1 / \alpha$, equation (29) has always one solution, $\bar{r}=\bar{r}\left(\mu_{0}, \alpha,\left[t_{S}-t_{A}\right]\right)$. Equation (29) also implies that $\bar{r}$ is a decreasing function of all three arguments. If $r>\bar{r}$, then $d\left(\Delta b_{t_{A}}\right) / d \mu_{1}$ evaluated at $\mu_{1}=\mu_{0}$ is positive, which means that tighter monetary policy is feasible, while looser monetary policy is not feasible. The opposite holds for $r<\bar{r}$.

Figure 2 illustrates the proposition for a particular choice of underlying parameters. An increase in the sustainable level of public debt following changes in expectations with respect to future monetary policy means that the actual level of public debt, which is predetermined by past macroeconomic policy, is lower than the current sustainable level. Thus the future shift in monetary policy is feasible, as it does not violate the sustainability constraint (13).

An important corollary following from (28) is that the change in the sustainable level of public debt as a function of the new growth rate of base money demonstrates its own Laffer-curve property. Indeed, while the first term in the right side of (28) decreases in $\mu_{1}$, the second term is the hump-shaped function of $\mu_{1}$. There are two major implications. First, the possibility to use preannounced monetary policy to generate gains in the present value of future seigniorage revenues is limited from above. Second, there are two levels of $\mu_{1}$ which allow the policy to achieve a certain attainable level of $\Delta b_{t_{A}}$ 10 Numerical calculations also show that in a regime of high interest rates (i.e., for $r>\bar{r}$ ), the higher the interest rate on

\footnotetext{
${ }^{10}$ The arising issue of indeterminacy is beyond the scope of this paper. It can be potentially addressed within the approach to an equilibrium selection device proposed by Acocella et al. (2014).
} 


\section{Figure 2. The Change in the Sustainable Level of Public Debt for Different Values of the Interest Rate}

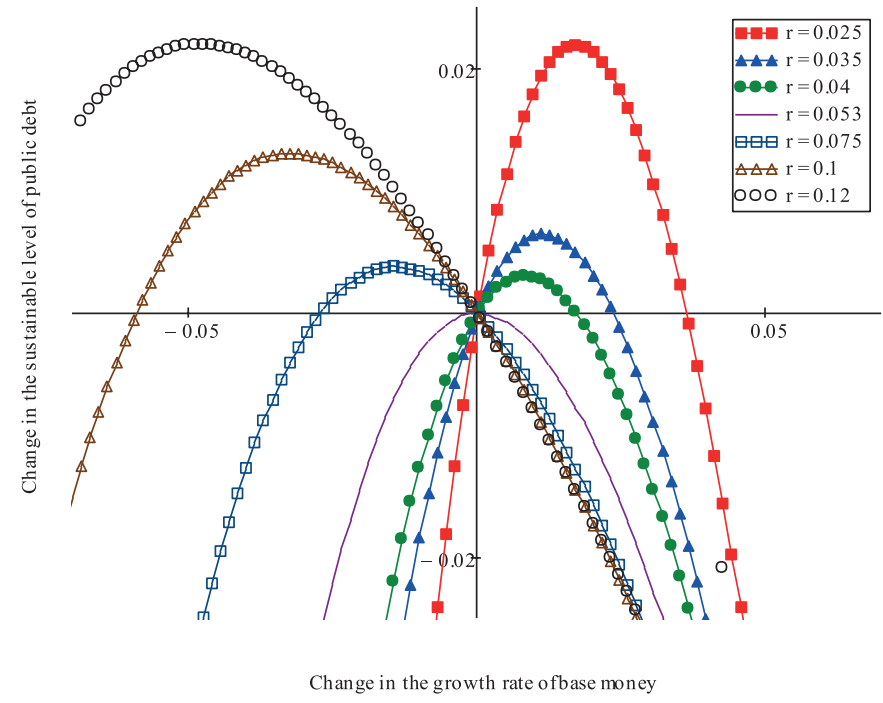

Notes: Underlying parameters are $\alpha=10, \mu_{0}=0.07$, and $t_{S}-t_{A}=10$. Tighter monetary policy $\left(\mu_{1}-\mu_{0}<0\right)$ is feasible for $r>0.053$; looser monetary policy $\left(\mu_{1}-\mu_{0}>0\right)$ is feasible for $r<0.053$.

public debt, the higher the maximal value of $\Delta b_{t_{A}}$ and the broader the range of feasible values of $\mu_{1}<\mu_{0}$. In a regime of low interest rates (i.e., for $r<\bar{r}$ ), the lower the interest rate, the higher the peak of $\Delta b_{t_{A}}$ and the broader the range of feasible values of $\mu_{1}>\mu_{0}$ (see figure 2).

The threshold value $\bar{r}$ is a decreasing function of the initial growth rate of base money $\mu_{0}$. This result implies that when $\mu_{0}$ and thus the initial rate of inflation are relatively high, it is more likely that the actual interest rate on public debt is above the threshold, which in turn makes an anticipated tight monetary policy feasible 11

\footnotetext{
${ }^{11}$ Quantitative exercises show that results are rather sensitive to the value of semi-elasticity of money demand and much less sensitive to the length of transitory dynamics. For example, roughly the same threshold value $\bar{r}=0.053$ is obtained for alternative specifications $\alpha=5, \mu_{0}=0.157$ and $\alpha=2, \mu_{0}=0.45$ given $t_{S}-t_{A}=10$, and $t_{S}-t_{A}=5, \mu_{0}=0.08$ and $t_{S}-t_{A}=2, \mu_{0}=0.09$
} 
Intuitively, given the semi-elasticity of money demand, the higher the inflation rate, the higher the full elasticity of the demand for real money balances. This in turn implies a stronger reaction to the anticipated change in monetary policy and thus a higher gain in seigniorage. In practice it means that monetary authorities in countries suffering from high inflation and a high interest rate on public debt are actually not subject to the tight money paradox if only they can make this proposed tightening credible 12 On the contrary, when the initial rate of inflation and the interest rate on public debt are relatively low, the transitional gain in seigniorage could be insufficient to make tight money feasible.

One can also consider another implication of the proposition. Assume that the government needs to increase the primary budget deficit now or in the future. (This is what happens, for example, during and in the aftermath of an economic recession.) It would be impossible in the absence of the adjustment of monetary policy, as it violates the sustainability constraint (13). Thus the question is how monetary policy can compensate for an increase in the present discounted value of future budget deficits. It follows that when the interest rate is relatively high, monetary policy should form expectations of a decrease in the growth rate of base money in the future. In other words, permanent fiscal expansion does not necessarily require an accompanying loose monetary policy resulting in higher inflation now or in the future.

Finally, implications are not actually limited by the assumption of fiscal dominance. In the case when fiscal authorities have to take monetary policy as given, a decrease in the present discounted value of seigniorage should be accompanied by a decrease in the present discounted value of future budget deficits. Thus one can easily interpret how anticipated tighter or looser monetary policy affects the set of alternatives for fiscal policy under different interest rates on public debt.

given $\alpha=10$. High sensitivity with respect to the semi-elasticity does not mean the fragility of the proposed solution to the tight money paradox, but implies different policy options for low- and high-inflation economies.

${ }^{12}$ Another practical issue that is absent in our forward-looking model is inflation inertia. 


\section{The Case of a Variable Real Interest Rate}

In the general case of non-separable utility, the real interest rate departs from its steady-state level $\rho$ along the transitional dynamics. Consider again a decrease in the growth rate of base money from $\mu_{0}$ to $\mu_{1}<\mu_{0}$, anticipated from time $t_{A}$, that takes place at time $t_{S} 13$ An increase in $m_{t}$ from time $t_{A}$ corresponds to a decrease in $i_{t}=U_{m}\left(c, m_{t}\right) / U_{c}\left(c, m_{t}\right)$, which falls below $i_{0}=\rho+\mu_{0}$. It follows from (11) and (12) that under conventional assumption $U_{c m}>0$, the real interest rate and inflation become lower, $r_{t}<\rho, \pi_{t}<\mu_{0}$ for $t_{A}<t<t_{S}$, notwithstanding the fact that the direction of transitional dynamics of $r_{t}$ and $\pi_{t}$ is ambiguous. At time $t_{S}$ the real interest rate jumps up to the steady level $\rho$, and inflation jumps to the steady level $\mu_{1}$. Qualitatively, the dynamics of seigniorage is the same as in the case of separable utility. The seigniorage jumps up at time $t_{A}$, then gradually increases, and finally jumps down to the lower steady level at time $t_{S}$. Moreover, in the case of non-separable utility, the transitory gain in seigniorage is supported by a temporal decrease in the real interest rate. The present discounted value of seigniorage over the interval $t_{A}<t<t_{S}$ increases even more.

To show that the case of pleasant monetarist arithmetic is possible, consider a non-separable utility of the form 14

$$
U(c, m)=\frac{\left(c^{\theta} m^{1-\theta}\right)^{1-\sigma}}{1-\sigma}, \quad 0<\theta<1, \quad 1-\frac{1}{\theta}<\sigma<1 .
$$

The demand for real money balances is given by

$$
m_{t}=\frac{1-\theta}{\theta} \frac{c}{i_{t}} \text {. }
$$

\footnotetext{
${ }^{13} \mathrm{An}$ unanticipated decrease in the growth rate of base money from $\mu=\mu_{0}$ to $\mu_{1}<\mu_{0}$ does not produce transitional dynamics. As in the case of separable utility, a downward jump in $\mu$ leads to an upward jump in $m$ and a downward jump in the nominal interest rate from $i_{0}=\rho+\mu_{0}$ to $i_{1}=\rho+\mu_{1}<i_{0}$. It follows from (11) and (12) that the real interest rate stays unchanged at $\rho$, and the rate of inflation jumps down from $\pi=\mu_{0}$ to $\pi=\mu_{1}$. Steady-state seigniorage falls along the increasing branch of the inflation-tax Laffer curve, and condition (13) is violated, which makes unanticipated monetary tightening infeasible.

${ }^{14}$ While (30) is the very special case of the CES-CRRA utility function with the unit elasticity of substitution between consumption and real money balances, this is the only specification that allows us to derive a closed-form forward-looking solution to (32), which is crucial for further analytical results.
} 
Equations (10)-(12) become

$$
\begin{aligned}
\frac{\dot{m}_{t}}{m_{t}} & =-\gamma\left(\frac{1-\theta}{\theta} \frac{c}{m_{t}}-\rho-\mu_{t}\right) \\
& =-\gamma\left(i_{t}-\rho-\mu_{t}\right), \\
\pi_{t} & =\gamma \frac{1-\theta}{\theta} \frac{c}{m_{t}}-\gamma \rho+(1-\gamma) \mu_{t} \\
& =\mu_{t}+\gamma\left(i_{t}-\rho-\mu_{t}\right), \\
r_{t}= & (1-\gamma) \frac{1-\theta}{\theta} \frac{c}{m_{t}}+\gamma \rho-(1-\gamma) \mu_{t} \\
= & \rho+(1-\gamma)\left(i_{t}-\rho-\mu_{t}\right),
\end{aligned}
$$

where $\gamma=(1+(1-\theta)(1-\sigma))^{-1}$. Imposing the transversality condition (9) gives the forward-looking solution to the linear differential equation (32):

$$
m_{t}=\gamma \frac{1-\theta}{\theta} c \int_{\tau=t}^{\infty} e^{-\int_{z=t}^{\tau} \gamma\left(\rho+\mu_{z}\right) d z} d \tau .
$$

The dynamics of real money balances

$$
m_{t}=\left\{\begin{array}{c}
\frac{1-\theta}{\theta} \frac{c}{\rho+\mu_{0}}, \quad t<t_{A}, \\
\frac{1-\theta}{\theta} \frac{c}{\rho+\mu_{0}}\left(1-e^{-\gamma\left(\rho+\mu_{0}\right)\left(t_{S}-t\right)}\right)+\frac{1-\theta}{\theta} \frac{c}{\rho+\mu_{1}} e^{-\gamma\left(\rho+\mu_{1}\right)\left(t_{S}-t\right)}, \\
\quad t_{A} \leq t<t_{S}, \\
\frac{1-\theta}{\theta} \frac{c}{\rho+\mu_{1}}, \quad t \geq t_{S}
\end{array}\right.
$$

replicates principal features of (24). There is an announcement jump at time $t_{A}$ and then a gradual increase until time $t_{S}$. Thus the dynamics of seigniorage is also similar to (26) 15 However, the behavior of inflation and real interest rate differs from the case of separable utility. Both of them jump twice, once at time $t_{A}$, following a jump in $m$, and later at time $t_{S}$, following a discrete change in $\mu .16$ The

\footnotetext{
${ }^{15}$ The inflation-tax function for the demand (31) monotonically increases in $\pi$ and does not have a hump-shaped Laffer-curve property.

${ }^{16}$ It follows from (31) and (35) that the nominal interest rate demonstrates a single jump at time $t_{A}$.
} 
direction of change in $\pi$ and $r$ depends on the parameter $\gamma$. Edgeworth complementarity, $U_{c m}>0$, corresponds to $\sigma<1$ and $\gamma<1$. In this case the rate of inflation discretely falls at time $t_{A}$ from the initial level $\mu_{0}$, then gradually decreases and jumps to the new steady level $\mu_{1}$ at time $t_{S}$. The real interest rate, which is initially at the steady level $r=\rho$, jumps down at time $t_{A}$, then gradually decreases and jumps up to $r=\rho$ at time $t_{S}$. Figure 3 illustrates the dynamics.

The principal finding of section 3.3 was that a sufficiently high real interest rate makes monetarist arithmetic pleasant. This result also holds for the case of non-separable utility. While analytical derivations are not possible here, we provide numerical examples. Table 1 presents threshold values of $\bar{r}$ such that for $\rho>\bar{r}$ an anticipated tightening of monetary policy leads to an increase in the present value of seigniorage at time $t_{A}$. However, in the case of nonseparable utility it is no longer true that, conversely, for any $\rho<\bar{r}$ an anticipated tightening decreases the present value of seigniorage. Table 1 also presents thresholds $\tilde{r}$ such that for $\rho<\tilde{r}$ an anticipated decrease in $\mu$ increases the present value of seigniorage at time $t_{A}$.

Sufficiently low $\rho$ 's make monetarist arithmetic pleasant due to a transitory decrease in the real interest rate. At time $t_{A}$, real money balances demonstrate a jump of the size $\Delta m_{t_{A}}=(1-\theta) \theta^{-1} c\left(\left(\rho+\mu_{1}\right)^{-1} e^{-\gamma\left(\rho+\mu_{1}\right)\left(t_{S}-t_{A}\right)}-\left(\rho+\mu_{0}\right)^{-1}\right.$ $\left.e^{-\gamma\left(\rho+\mu_{0}\right)\left(t_{S}-t_{A}\right)}\right)>0$, which is decreasing in $\rho 17$ In turn, the higher the upward jump in $m$, the higher the jump in $S$ and the deeper the fall in $r 18$ The former conclusion follows from the definition of seigniorage and the constancy of $\mu$ at time $t_{A}$, while the latter conclusion follows from equation (34). It means both higher transitory seigniorage and its slighter discounting in the presentvalue calculation. For $\rho<\tilde{r}$ these two effects outweigh the impact from the long-run decrease in seigniorage.

For any $\rho$ in the range $\tilde{r}<\rho<\bar{r}$, an anticipated monetary policy tightening is not feasible. In this case $\rho$ is neither sufficiently high to

\footnotetext{
${ }^{17}$ Note that in the case of separable utility (Cagan demand for money) the change in the log of real money balances and seigniorage does not depend on $\rho$.

${ }^{18}$ The downward jump in seigniorage at time $t_{S}$ depends only on the ratio $\mu_{1} / \mu_{0}$.
} 
Figure 3. Permanent Anticipated Decrease in the Growth Rate of Base Money under a Variable Real Interest Rate
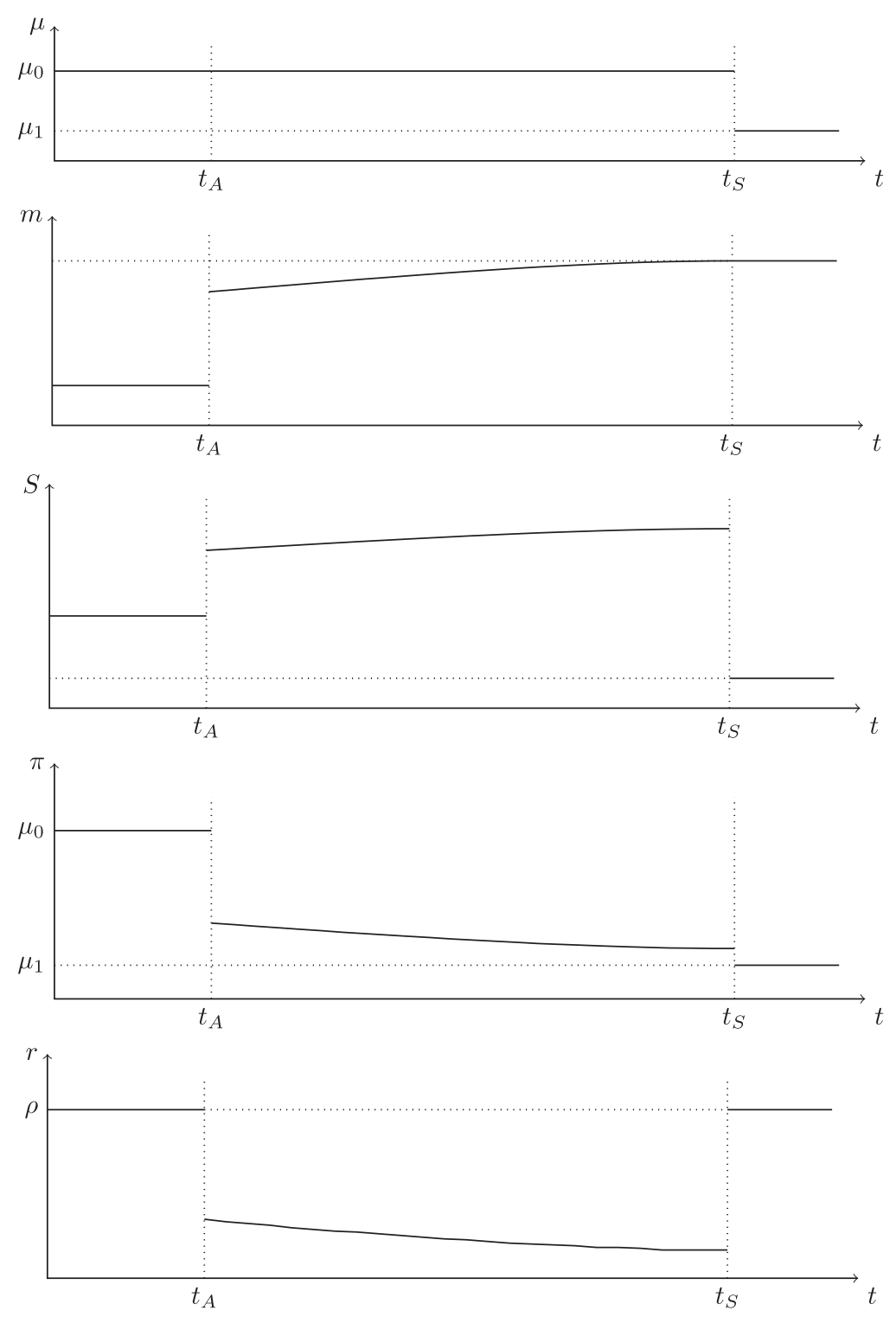


\section{Table 1. Threshold Values of the Real Interest Rate in the Case of an Anticipated Decrease in the Growth Rate of Base Money}

\begin{tabular}{|c|c|c|c|c|c|c|c|c|}
\hline & $\boldsymbol{\sigma}$ & $\mathbf{0 . 0 2}$ & $\mathbf{0 . 0 5}$ & $\mathbf{0 . 1}$ & $\mathbf{0 . 2 5}$ & $\mathbf{0 . 5}$ & $\mathbf{0 . 7}$ & $\mathbf{0 . 9}$ \\
\hline$\theta=0.85$ & $\bar{r}$ & 0.040 & 0.046 & 0.052 & 0.068 & 0.087 & 0.103 & 0.125 \\
& $\tilde{r}$ & 0.037 & 0.029 & 0.024 & 0.017 & 0.009 & 0.005 & 0.002 \\
\hline$\theta=0.9$ & $\bar{r}$ & 0.075 & 0.076 & 0.077 & 0.087 & 0.105 & 0.111 & 0.120 \\
& $\tilde{r}$ & 0.014 & 0.013 & 0.012 & 0.009 & 0.002 & 0.002 & 0.001 \\
\hline
\end{tabular}

Note: Underlying parameters are $\mu_{0}=0.07, \mu_{1}=0.05$, and $t_{S}-t_{A}=10$.

generate the effect of heavy discounting of lower long-run seigniorage nor sufficiently low to give rise to two effects of the transitional dynamics that are discussed above.

The threshold $\tilde{r}$ decreases with an increase in $\sigma$ and $\theta$, while the threshold $\bar{r}$ is an increasing function of both parameters. The lower $\sigma$ and $\theta$, the lower $\gamma$, which in turn produces higher transitional gain in seigniorage and deeper transitional fall in the real interest rate 19 Thus, when $\sigma$ and $\theta$ are high, for monetary policy tightening to be feasible, the real interest rate should be either sufficiently low to generate the effect of transitional gain in seigniorage supported by a slighter discounting or sufficiently high to heavily discount the long-run decrease in seigniorage. Conversely, when $\sigma$ and $\theta$ are low, thresholds $\tilde{r}$ and $\bar{r}$ are close to each other. Moreover, there are values of $\sigma$ and $\theta$ such that $\tilde{r}=\bar{r}$ (e.g., $\sigma=0.19$ and $\theta=0.85$ ) and further decrease in $\sigma$ or $\theta$ causes thresholds to vanish, which makes monetarist arithmetic pleasant for any real interest rate.

As we have shown in section 3.3 for the case of a constant real interest rate, not only a decrease but also an increase in the growth rate of base money can be subject to unpleasant monetarist arithmetic. In the case of a variable real interest rate, an anticipated monetary policy loosening is not always feasible as well. It follows from (33)-(35) that under assumption $U_{c m}>0$ a decrease in $\mu$ from time $t_{S}$, anticipated at time $t_{A}$, produces downward announcement

\footnotetext{
${ }^{19}$ For the general form of non-separable utility (including general CES-CRRA specification), $\gamma$ depends on $m_{t}$. Unfortunately, this parameter does not have a simple interpretation.
} 


\section{Table 2. Threshold Values of the Real Interest Rate in the Case of an Anticipated Increase in the Growth Rate of Base Money}

\begin{tabular}{|l|c|c|c|c|c|c|c|c|}
\hline & $\boldsymbol{\sigma}$ & $\mathbf{0 . 0 2}$ & $\mathbf{0 . 0 5}$ & $\mathbf{0 . 1}$ & $\mathbf{0 . 2 5}$ & $\mathbf{0 . 5}$ & $\mathbf{0 . 7}$ & $\mathbf{0 . 9}$ \\
\hline$\theta=0.85$ & $\bar{r}$ & - & - & - & 0.053 & 0.090 & 0.114 & 0.137 \\
& $\tilde{r}$ & - & - & - & 0.040 & 0.017 & 0.009 & 0.002 \\
\hline$\theta=0.9$ & $\bar{r}$ & 0.066 & 0.067 & 0.079 & 0.089 & 0.106 & 0.121 & 0.138 \\
& $\tilde{r}$ & 0.027 & 0.025 & 0.023 & 0.019 & 0.009 & 0.005 & 0.001 \\
\hline
\end{tabular}

Note: Underlying parameters are $\mu_{0}=0.07, \mu_{1}=0.09$, and $t_{S}-t_{A}=10$.

jumps in $m$ and $S$, and upward jumps in $\pi$ and $r$. The demand for real money balances gradually decreases to the new steady level. Seigniorage also incurs a transitional decrease before it jumps up to the new steady level at time $t_{S}$. The rate of inflation and the real interest rate rise along their transitional paths. At time $t_{S}$ inflation jumps up to the new steady level, while the real interest rate falls to its steady level $\rho$.

To evaluate the change in the present value of future seigniorage at time $t_{A}$, we should focus on the same factors which contribute to the transitory loss and the long-run gain in seigniorage. First, for the present-value calculation, higher values of $\rho$ imply heavy discounting of the long-run gain in seigniorage which becomes higher at time $t_{S}$. Table 2 presents thresholds $\bar{r}$ such that for any $\rho>\bar{r}$ an anticipated increase in $\mu$ decreases the present value of seigniorage at time $t_{A}$. Second, the lower $\rho$, the deeper the downward jump in $m$ and $S$ at time $t_{A}$, and the higher the transitional rise in $r$. While in the case of anticipated policy tightening both higher transitory $S$ and lower transitory $r$ give positive contributions to the present value of seigniorage, here a fall in $S$ and a rise in $r$ work in opposite directions with respect to the present value of seigniorage. For the functional specification that we employ, the positive impact of heavier transitional discounting for relatively low values of $\rho$ does not outweigh the negative impact of deeper transitional fall in $S$. Table 2 reports thresholds $\tilde{r}$ such that for any $\rho<\tilde{r}$ an anticipated monetary policy loosening is infeasible. The threshold $\tilde{r}$ decreases in $\theta$ and $\sigma$, while the threshold $\bar{r}$ increases in both parameters. 
Moreover, there are $\theta$ and $\sigma$ such that $\tilde{r}=\bar{r}$ (e.g., $\theta=0.85$ and $\sigma=0.23$ give $\tilde{r}=\bar{r}=0.49$ ) and for smaller parameter values anticipated loosening in monetary policy is infeasible for any $\rho$.

\section{Discussion}

\subsection{FTI, FTPL, and Monetary Policy Instruments}

Our search for the case of pleasant monetarist arithmetic was carried out in the traditional framework of the fiscal theory of inflation (FTI, hereafter). One would naturally question the validity of the results obtained in the framework of novel fiscal theory of the price level (FTPL, hereafter). It seems useful to split the message of Sargent and Wallace (1981) in two: (i) monetary policy tightening may not be feasible under fiscal dominance and (ii) permanently unadjusted fiscal deficits may have inflationary consequences. Below we aim to show that while FTPL resembles in an alternative way the latter, it hardly deals with the former. To do this we have to rewrite and reinterpret equation (13) in line with FTPL:

$$
\frac{M_{t}+B_{t}}{P_{t}}=\int_{\tau=t}^{\infty}\left(i_{\tau} m_{\tau}-d\right) e^{\int_{z=t}^{\tau} r_{z} d z} d \tau
$$

Equation (37) is the forward-looking solution to (4) for the total government and central bank liabilities $m_{t}+b_{t} 20$ The seigniorage revenue is measured as $i_{t} m_{t} 21$ While a traditional monetarist approach treats (13) as an intertemporal government budget constraint which should be met for any price level, FTPL interprets (37) as a valuation equation that pins down the equilibrium price level. Whenever the real value of total liabilities on the left-hand side of (37) deviates from the backing which is represented by the right-hand side of (37), the price level should adjust to equate them. Two underlying

\footnotetext{
${ }^{20}$ In deriving (37) one has to impose the transversality condition for the sum of liabilities, $\lim _{t \rightarrow \infty} \lambda_{t}\left(m_{t}+b_{t}\right) e^{-\rho t}=0$, not for $b_{t}$ and $m_{t}$ separately. This is one of the differences between the traditional approach and FTPL.

${ }^{21}$ The discussion below shows that the precise definition of seigniorage ( $\mu \mathrm{m}$ or $\mathrm{im}$ ) does not affect results.
} 
assumptions behind this interpretation are that public debt is nominal (non-indexed) and that the monetary policy instrument is the nominal interest rate, not the growth rate of base money 22

Consider first the case of an unexpected increase in the nominal interest rate at time $t_{S}$ from $i_{0}$ to $i_{1}$. It follows from (6)-(8) that the real interest rate remains the same, $r=\rho$, while inflation and the growth rate of base money jump from $\pi=\mu=i_{0}-\rho$ to $\pi=\mu=$ $i_{1}-\rho$. Assume again that the economy is on the increasing branch of the inflation-tax Laffer curve. Thus monetary policy tightening leads to an increase in seigniorage from $i_{0} m\left(i_{0}\right)$ to $i_{1} m\left(i_{1}\right)$. Given $B_{t_{S}}$, an increase in the backing of public liabilities in line with FTPL requires a fall in the price level from $P_{t_{S}^{-}}=r B_{t_{S}} /\left(\left(i_{0}-\rho\right) m\left(i_{0}\right)-d\right)$ to $P_{t_{S}^{+}}=r B_{t_{S}} /\left(\left(i_{1}-\rho\right) m\left(i_{1}\right)-d\right)<P_{t_{S}^{-}}$. Base money is endogenously determined and undergoes a discrete decrease from $M_{t_{S}^{-}}=$ $m\left(i_{0}\right) P_{t_{S}^{-}}$to $M_{t_{S}^{+}}=m\left(i_{1}\right) P_{t_{S}^{+}}<M_{t_{S}^{-}}$.

Consider next the same experiment with an announcement at time $t_{A}<t_{S}$ of a future monetary policy tightening starting from time $t_{S}$. By setting constant $i_{t}=i_{0}$ for $t<t_{S}$, the central bank fixes $m_{t}=m\left(i_{0}\right)$. Thus forming at time $t_{A}$ expectations of an increase in the nominal interest rate to $i_{t}=i_{1}>i_{0}$ starting from time $t_{S}$ does not produce any transitory dynamics in the demand for real money balances before time $t_{S}$. But as agents expect an increase in the seigniorage $i_{t} m_{t}$ from time $t_{S}$, it leads to an increase in the backing of public liabilities. Given $B_{t_{A}}$, an increase in the backing requires downward jumps in $P_{t_{A}}$ and $M_{t_{A}}$ :

$$
\begin{aligned}
P_{t_{A}^{+}}-P_{t_{A}^{-}}= & \frac{r B_{t_{A}}}{\left(i_{0}-r\right) m\left(i_{0}\right)+\left(i_{1} m\left(i_{1}\right)-i_{0} m\left(i_{0}\right)\right) e^{-r\left(t_{S}-t_{A}\right)}-d} \\
- & \frac{r B_{t_{A}}}{\left(i_{0}-r\right) m\left(i_{0}\right)-d}<0 \\
& M_{t_{A}^{+}}-M_{t_{A}^{-}}=m\left(i_{0}\right)\left(P_{t_{A}^{+}}-P_{t_{A}^{-}}\right)<0 .
\end{aligned}
$$

However, these are just jumps in levels, not in growth rates. Indeed, given constant demand for real money balances $m\left(i_{0}\right)$ for $t<t_{S}$,

\footnotetext{
${ }^{22}$ If the central bank sets the growth rate of base money, then equilibrium inflation and price level are determined in the way that we describe in section 2 . This leaves no room for the mechanism of FTPL.
} 
equations (6)-(8) determine constant $\lambda=U_{c}\left(c, m\left(i_{0}\right)\right), r=\rho$ and $\pi=\mu=i_{0}-\rho$. At time $t_{S}$ the rate of inflation and the growth rate of base money jump to $\pi=\mu=i_{1}-\rho$. Interestingly, while the expected backing of total government liabilities does not demonstrate a jump at time $t_{S}$, as real money balances undergo a discrete decrease from $m\left(i_{0}\right)$ to $m\left(i_{1}\right)$ the price level and the base money jump down the second time:

$$
\begin{gathered}
P_{t_{S}^{+}}-P_{t_{S}^{-}}=\frac{r B_{t_{S}}}{i_{1} m\left(i_{1}\right)-r m\left(i_{0}\right)-d}-\frac{r B_{t_{S}}}{\left(i_{1}-r\right) m\left(i_{1}\right)-d}<0, \\
M_{t_{S}^{+}}-M_{t_{S}^{-}}=m\left(i_{1}\right) P_{t_{S}^{+}}-m\left(i_{0}\right) P_{t_{S}^{-}}<0 .
\end{gathered}
$$

Should we interpret these results as (i) the framework of FTPL allowing the replication of UMA, and (ii) there being no case for pleasant monetarist arithmetic, which is based on the transitory dynamics of seigniorage? Both statements are subject to certain reservations.

First, while it is often asserted that FTPL leads to the same conclusions as UMA, it would be more accurate to refer the former to FTI, not to UMA per se. Indeed, equation (37) says that an increase in fiscal deficits directly leads to an increase in the price level, while FTI implies inflationary consequences of fiscal deficits via higher seigniorage. At the same time, the precise logic of UMA is often misrepresented in the FTPL literature.

Second, while we show that in the framework of FTPL monetary policy tightening leads to higher inflation, albeit accompanied by an initial fall in the price level, this result has nothing to do with UMA. Indeed, here higher inflation does not result from the logic of consolidated budget constraint or equation (37). It directly follows from an increase in the nominal interest rate in an endowment economy where the central bank does not influence the real interest rate 23 Moreover, policy tightening in the form of higher nominal interest rate is associated with higher seigniorage, which in turn leads to the initial fall in the price level. It means that the logic of consolidated budget constraint works here in the opposite direction.

\footnotetext{
${ }^{23}$ See Cochrane (2016) for an extensive discussion of this "neo-Fisherian" result of the frictionless model.
} 
Third, while in the traditional monetarist approach the real interest rate does not react to monetary policy only under an additively separable utility function, in the FTPL this is the case because by setting the nominal interest rate, the central bank fixes the demand for real money balances, which together with constant consumption makes the real interest rate constant as well. In a more general setup where changes in the nominal interest rate affect real interest rate, one could expect richer transitory dynamics. Specifically, the announcement at time $t_{A}$ of an increase in the nominal interest rate from $i_{0}$ to $i_{1}$ starting from time $t_{S}$ should produce an increase in the real interest rate and a decrease in inflation, while their sum constitutes the same constant nominal interest rate $i_{0}$. The anticipated future increase in seigniorage from $i_{0} m\left(i_{0}\right)$ to $i_{1} m\left(i_{1}\right)$ increases the backing of total government liabilities in (37), but an increase in the real interest rate leads to a decrease in the backing. The overall effect is ambiguous, which means that anticipated monetary policy tightening does not necessary lead to higher inflation or an upward jump in the price level. This resembles the possibility of pleasant monetarist arithmetic that we discussed in previous sections.

Finally, we reevaluate the consequences of monetary policy tightening in the form of an increase in the constant nominal interest rate. This is the simplest passive monetary policy rule, while our specification of the fiscal policy corresponds to the active fiscal rule in the terminology of FTPL. It is well known that FTPL is sensible for this fiscal-monetary mix of rules (see, e.g., an intensive discussion in Woodford 2003). As follows from the previous discussion, introducing the Taylor rule of the form $i_{t}=i^{*}+\varphi\left(\pi-\pi^{*}\right)$ and considering changes in the inflation target $\pi^{*}$ or in the strength of reaction $\varphi^{\prime}(\cdot)$ would not change principal results. Instead, surprisingly, monetary policy can achieve lower steady-state inflation, albeit accompanied with a one-time jump in the price level, by decreasing nominal interest rates. This makes higher demand for real money balances compatible with lower inflation.

\subsection{Endogenous Budget Deficits}

Following the UMA literature, we assume that monetary policy does not affect fiscal deficits. Dornbusch (1996), among others, suggests 
that tight monetary policy may worsen the fiscal position by depressing economic activity and lowering tax revenues. On the one hand, if tighter monetary policy leads to higher budget deficits, then an increase in the present discounted value of future seigniorage which we explore could be insufficient to compensate for the higher present discounted value of future budget deficits 24 In this case the possibility of a transitory gain in seigniorage does not make anticipated tighter monetary policy feasible. On the other hand, as the experience of high-inflation economies suggests, by stabilizing extreme inflation, tighter monetary policy can stimulate depressed economic activity and thus improve the fiscal position (see, e.g., Bruno and Easterly 1998; and Fischer, Sahay, and Vegh 2002). This makes the case of pleasant monetarist arithmetic that we explore feasible.

We can also consider the opposite situation: if one believes that expectations of looser monetary policy in the future can stimulate economic activity and increase tax revenues, does it unambiguously restore the sustainability of public debt? Hellebrandt, Posen, and Tolle (2012) show on the data set of 173 episodes from seventeen advanced economies over the last three decades that loose monetary policy tends to precede successful and credible fiscal consolidation, which is an urgent issue for many countries today. Our analysis cautions that while an unanticipated monetary policy loosening always increases the present value of seigniorage, an anticipated loosening can destroy the sustainability of public debt if the real interest rate is either relatively high or lower than a certain threshold. Moreover, we show that there are cases when expectations of a decrease in the growth rate of base money bring forth a decrease in the present value of future seigniorage for any real interest rate, which undermines the efforts of fiscal consolidation.

\subsection{Some Practical Implications}

Several practical issues arise in light of the proposed solution to the tight money paradox. First, apart from the numerical example in the previous section, does the transitory gain in seigniorage constitute an important element of the public finance in practice? Second, how

\footnotetext{
${ }^{24}$ Piergallini and Rodano (2012) explore the relation between Laffer curves for inflation tax and income tax.
} 
can we address the issue of the inflationary consequences of public debt in developed and developing economies? Third, can we make some inference on the current monetary-fiscal stance?

One would naturally expect the transitory gain in seigniorage to be important when seigniorage is itself an important part of public finance 25 In the discussion of the successful stabilization of high inflation in Israel, Bruno (1993, p. 46) documents a substantial increase in the revenue from base money creation from 2.9 percent of GNP in 1984 to 5.9 percent in 1985 before it fell to almost zero in subsequent years. The success of this stabilization program in reducing inflation from more than 400 percent in the late 1984 to a modest 15-20 percent in the following years leaves little doubt that the permanently tighter monetary policy was initially perceived as credible. The drop in inflation rate actually led the decrease in the growth rate of base money from its peak of 400 percent in January 1985 to a two-digit range from 1987, which is in line with the case of pleasant monetarist arithmetic obtained in sections 3 and 5 of this paper 26 The temporary success of the Austral Plan in Argentina in 1985 provides another example. The annual inflation rate decreased from its peak of 1,129 percent in July 1985 to 50 percent in July 1986. Following the announcement of a monetary policy tightening, the drop in inflation also led the reduction in the growth rate of money from more than 900 percent in mid-1985 to a two-digit range in mid-1986. At the same time, seigniorage revenue temporary increased from 6.8 percent of GDP in the second quarter of 1985 to 8.9 percent of GDP in the third quarter of 1985 before it fall to less than 4 percent of GDP in 1986 (see Heymann 1991).

The proposed solution to the tight money paradox allows us to provide insight into another problem. FTI predicts that budget deficits are inflationary either in the short run or in the long run 27

\footnotetext{
${ }^{25}$ We discuss two case studies from developing economies. However, while seigniorage is perceived to be negligible as a percent of GDP, historically it is nonnegligible as a share of government spending even in some developed economies. See, e.g., Click (1998).

${ }^{26}$ However, this should not be interpreted as the pure monetarist explanation of the success. While the transitory gain in seigniorage was indeed significant, the main key to success was dramatic reduction in budget deficits. See Bruno (1993) for detailed discussion.

${ }^{27}$ Drazen and Helpman (1990) stress that the theory does not predict the strong correlation between budget deficits and inflation that is due to uncertainty about
} 
However, empirical evidence supports this view mostly for highly indebted developing countries with extreme or moderate inflation, but not for major developed economies (see, e.g., King and Plosser 1985; Fischer, Sahay, and Vegh 2002; Catão and Terrones 2005; Giannitsarou and Scott 2006; Kwon, McFarlane, and Robinson 2009; and Lin and Chu 2013, among others). On the one hand, historically, it may have been the case that in developed economies the government (not the central bank) adjusted its policy at times when public debt became high (see, e.g., Afonso 2008; Mendoza and Ostry 2008). That is, in the past, contrary to the principal assumption of UMA, fiscal policy was not dominant over monetary policy 28 Yet, at present, this is hardly an option for many countries under fiscal stress. On the other hand, if there is indeed a possibility for tight money to have "pleasant arithmetic" under the conditions derived in sections 3 and 4 , then the inflationary consequences of budget deficits are not inevitable even under the regime of fiscal dominance. We confirm that in this case an increase in the budget deficit can be accompanied by tight (and low-inflation) monetary policy. Thus, an appropriate case study is a good alternative to the cross-country analysis that may help to clarify whether and when budget deficits are inflationary 29

The current fiscal-monetary nexus in developed economies questions the relevance of the empirical evidence of the absence of inflationary consequences of public debt in the pre-crises period. Many countries that experience fiscal stress today are likely to switch to a regime of fiscal dominance. This means that while in the last decades UMA was not viewed as a practical issue, now it should be seriously taken into account. Moreover, for the United States there are projections of the Federal Reserve's negative remittances to the

the type and timing of future policy shifts. We come to the same conclusion, but from different arguments.

${ }^{28}$ Indeed, even the latest studies on inflationary consequences of public debt cited above use the data set prior to the 2008-09 crises.

${ }^{29}$ Buffie (2003b) provides such a case study of inflationary episodes in subSaharan African countries and describes quite different consequences of tight monetary policies. Salomon (2001) finds empirical support for UMA using a nonlinear time-series model to study inflation in Brazil. The jump in inflation in Israel in 1983 can be explained by expectations of a large government bailout of commercial banks just in line with UMA (see Sargent and Zeira 2011). 
Treasury following its extraordinary balance sheet expansion (see, e.g., Greenlaw et al. 2013). However, our analysis in sections 3 and 4 suggests that when the long-run real interest rate on public debt is either relatively high or below a certain threshold, an anticipated monetary policy tightening is feasible without fiscal adjustment. As the real interest rate remains at historical lows in the United States and other developed countries and there are expectations of future monetary policy tightening (indeed, gradual monetary policy tightening is on the way in the United States), the case of pleasant monetarist arithmetic seems plausible.

\section{Conclusion}

Monetary policy tightening is subject to a well-known theoretical paradox: a temporary reduction in seigniorage without appropriate fiscal adjustment leads to a faster accumulation of public debt, which results in higher inflation in the future, at best, or higher inflation immediately, at worst. Taking this unpleasant monetarist arithmetic seriously implies the threat of higher inflation in modern developed economies under fiscal stress. However, the bulk of the literature on unpleasant monetarist arithmetic does not take into account the possibility of a transitory gain in seigniorage in the case of a gradual or anticipated monetary policy tightening. In this paper we argue that the anticipation of a decrease in the growth rate of base money in the future can generate a short-term gain in seigniorage, which is sufficient to avoid a decrease in its present discounted value and keep public debt on a sustainable path without otherwise necessary fiscal adjustment. It implies that anticipated tighter monetary policy is not subject to unpleasant monetarist arithmetic and can be implemented without fiscal adjustment. On the contrary, within this regime an increase in budget deficits now or in the future does not require looser monetary policy and higher inflation: in fact, monetary authorities should form expectations of a decrease in the growth rate of base money.

The present discounted value of seigniorage depends crucially on the interest rate on public debt. We show that an anticipated monetary policy tightening is feasible when the real interest rate is either sufficiently high or relatively low. On the one hand, a high interest 
rate may be seen as a strengthening factor for the tight money paradox: the higher the interest rate, the faster public debt grows following the initial cut in seigniorage revenue. However, if there is a transitional gain in seigniorage instead of a loss, the role of a high interest rate is reversed. A higher interest rate implies a higher discounting of future revenues, and thus a short-run gain in seigniorage becomes more important than its long-run decrease. On the other hand, we show that the lower the steady-state real interest rate, the higher the transitional gain in seigniorage, and the deeper the transitional fall in the real debt service rate in the case of non-separable utility. When the steady-state real interest rate is below a certain threshold, these effects imply an increase in the present value of seigniorage despite the fact that its long-run fall is more slightly discounted.

In practice, these conclusions imply that expectations of future monetary policy tightening do not inevitably impose an increase in inflation in two situations: in developing countries facing extremely high interest rates on public debt and in developed economies which have an advantage of close-to-zero debt service rate. On the other hand, when the real interest rate is modestly high, either an unanticipated or an anticipated tightening of monetary policy is subject to unpleasant monetarist arithmetic.

\section{References}

Acocella, N., G. Di Bartolomeo, A. Hughes Hallet, and P. G. Piacquadio. 2014. "Announcements as an Equilibrium Selection Device." Oxford Economic Papers 66 (1): 325-47.

Afonso, A. 2008. "Ricardian Fiscal Regimes in the European Union." Empirica 35 (3): 313-34.

Bhattacharya, J., and N. Kudoh. 2002. "Tight Money Policies and Inflation Revisited." Canadian Journal of Economics 35 (2): $185-217$.

Bruno, M. 1993. Crisis, Stabilization, and Economic Reform. Oxford: Clarendon Press.

Bruno, M., and W. Easterly. 1998. "Inflation Crises and Long-Run Growth." Journal of Monetary Economics 41 (1): 3-26.

Buffie, E. F. 2003a. "Policy Rules and Monetarist Arithmetic." Bulletin of Economic Research 55 (3): 223-47. 
2003b. "Tight Money, Real Interest Rates, and Inflation in Sub-Saharan Africa." IMF Staff Papers 50 (1): 115-35.

Catão, L., and M. Terrones. 2005. "Fiscal Deficits and Inflation." Journal of Monetary Economics 52 (3): 529-54.

Chadha, J. S., and C. Nolan. 2004. "Interest Rate Bounds and Fiscal Policy." Economics Letters 84 (1): 9-15.

Click, R. W. 1998. "Seigniorage in a Cross-Section of Countries." Journal of Money, Credit and Banking 30 (2): 154-71.

Cochrane, J. H. 2011. "Understanding Policy in the Great Recession: Some Unpleasant Fiscal Arithmetic." European Economic Review 55 (1): 2-30.

_ 2016. "Do Higher Interest Rates Raise or Lower Inflation?" Mimeo.

Dornbusch, R. 1996. "Debt and Monetary Policy: The Policy Issues." NBER Working Paper No. 5573.

Drazen, A. 1985. "Tight Money and Inflation: Further Results." Journal of Monetary Economics 15 (1): 113-20.

Drazen, A., and E. Helpman. 1990. "Inflationary Consequences of Anticipated Macroeconomic Policies." Review of Economic Studies 57 (1): 147-66.

Fischer, S., R. Sahay, and C. A. Vegh. 2002. "Modern Hyper- and High Inflations." Journal of Economic Literature 40 (3): 837-80.

Giannitsarou, C., and A. Scott. 2006. "Inflation Implications of Rising Government Debt." NBER Working Paper No. 12654.

Greenlaw, D., J. D. Hamilton, P. Hooper, and F. S. Mishkin. 2013. "Crunch Time: Fiscal Crises and the Role of Monetary Policy." NBER Working Paper No. 19297.

Hellebrandt, T., A. S. Posen, and M. Tolle. 2012. "Does Monetary Cooperation or Confrontation Lead to Successful Fiscal Consolidation?" Financial Stability Review (Banque de France) 16 (April): 131-42.

Heymann, D. 1991. "From Sharp Disinflation to Hyperinflation, Twice: The Argentine Experience, 1985-1989." In Lessons of Economic Stabilization and Its Aftermath, ed. M. Bruno, S. Fischer, E. Helpman, and N. Livitan, 103-30. Cambridge, MA: MIT Press.

King, R. G., and C. I. Plosser. 1985. "Money, Deficits, and Inflation." Carnegie-Rochester Conference Series on Public Policy 22: 147-96. 
Kwon, G., L. McFarlane, and W. Robinson. 2009. "Public Debt, Money Supply, and Inflation: A Cross-Country Study." IMF Staff Papers 56 (3): 476-515.

Leeper, E. M., and T. B. Walker. 2011. "Fiscal Limits in Advanced Economies." Economic Papers: A Journal of Applied Economics and Policy 30 (1): 33-47.

Lin, H.-Y., and H.-P. Chu. 2013. "Are Fiscal Deficits Inflationary?" Journal of International Money and Finance 32 (February): 21433.

Mendoza, E. G., and J. D. Ostry. 2008. "International Evidence on Fiscal Solvency: Is Fiscal Policy 'Responsible'?" Journal of Monetary Economics 55 (6): 1081-93.

Nikitin, M., and S. Russell. 2006. "Monetary Policy Arithmetic: Reconciling Theory with Evidence." Canadian Journal of Economics 39 (1): 348-74.

Piergallini, A., and G. Rodano. 2012. "Public Debt, Distortionary Taxation, and Monetary Policy." Rivista Italiana Degli Economisti 2: 225-48.

Reis, R. 2015. "Different Types of Central Bank Insolvency and the Crucial Role of Seigniorage." NBER Working Paper No. 21226. Salomon, M. F. 2001. "The Inflationary Consequences of Fiscal Policy in Brazil: An Empirical Investigation with Regime Switches and Time-Varying Probabilities." Studies in Nonlinear Dynamics and Econometrics 5 (1): 41-56.

Sargent, T. J., and N. Wallace. 1973. "The Stability of Models of Money and Growth with Perfect Foresight." Econometrica 41 (6): 1043-48.

_. 1981. "Some Unpleasant Monetarist Arithmetic." Quarterly Review (Federal Reserve Bank of Minneapolis) 5 (3, Fall): 1-17. Sargent, T. J., and J. Zeira. 2011. "Israel 1983: A Bout of Unpleasant Monetarist Arithmetic." Review of Economic Dynamics 14 (3): 419-31.

Sims, C. A. 1994. "A Simple Model for the Determination of the Price Level and the Interaction of Monetary and Fiscal Policy." Economic Theory 4 (3): 381-99.

Turnovsky, S. J. 2000. Methods of Macroeconomic Dynamics. 2nd ed. Cambridge, MA: MIT Press. 
Uribe. M. 2016. "Is the Monetarist Arithmetic Unpleasant?" NBER Working Paper No. 22866.

Woodford, M. 1995. "Price-Level Determinacy without Control of a Monetary Aggregate." Carnegie-Rochester Conference Series on Public Policy 43 (December): 1-46.

- 2003. Interest and Prices: Foundations of a Theory of Monetary Policy. Princeton, NJ: Princeton University Press. 